\title{
EDITORIAL
}

\section{FORTALECIMIENTO INSTITUCIONAL}

La Facultad de Ciencias Veterinarias de la Universidad Nacional de Asuncion desde su fundación estuvo inmersa al desarrollo e incremento de sus capacidades para llevar a cabo sus fines sustantivos.

Esto implica tomar en cuenta el concepto de institución como una serie de comportamientos y normas que perduran en el tiempo y que persiguen unos propósitos valorados por la sociedad. En éste caso la FCV tiene un acervo de características propias que se traducen en su proyecto institucional, en su diseño organización y su vinculación con el medio; asi como en el manejo de los talentos humanos y materiales. El fortalecimiento institucional debe considerar estas características y posibilitar su alineamiento.

Entre los objetivos del fortalecimiento institucional de la FCV-UNA se cuentan:

a) Promover y contribuir a la mejora de la calidad educativa

b) Aportar a los procesos de la acreditación de la carrera, y

c) Contribuir al cumplimiento de la misión y visión de la institución.

Con esto se pretende crear un camino por donde transitar en el ejercicio de la profesión veterinaria recuperando la confianza entre los miembros de la comunidad universitaria y la sociedad que espera seriedad, responsabilidad y la vocación de mejora continua.

No puede existir una buena gobernanza sin lograr el equilibrio entre la integridad, transparencia y eficacia, y la correcta jerarquización de actuaciones bajo principios capaces de aglutinar concenso y tener sentido de pertenencia institucional.

Prof. Dra. Elizabeth Nuñez Grüner, M.Sc Directora de la Revista "Compendio de Ciencias Veterinarias" 


\section{EDITORIAL}

\section{INSTITUTIONAL STRENGTHENING.}

The Faculty of Veterinary Sciences of the National University of Asuncion since its foundation was immersed in the development and increase of its capacities to carry out substantive purposes. This implies taking into account the concept of institution as a series of behaviors and norms that endure over time and that pursuing a purpose valued by society.

In this case, the FCV has a collection of its own acquis that are translated into its institutional project, its design, organization and its link with the environment, likewise in the management of human and material talents. Institutional strengthening should consider these characteristics and enable their alignment

Among the objectives of the institutional strengthening of FCV-UNA are to:

a) Promote and contribute to the improvement of educational quality

b) Contribute to the processes of the career accreditation

c.) Contribute to the fulfillment of the mission and vision of the institution

This is intended to create a path through which to transit in the exercise of the veterinary profession, recovering the trust between the members of the university, community and the society that expects seriousness, responsibility and the vocation of continuous improvement.

There can be no good governance without achieving a balance between integrity, transparency and efficiency, and the correct hierarchization of actions under principles capable of bringing together consensus and having a sense of institutional belonging.

Prof. Dra. Elizabeth Nuñez Grüner, M.Sc Director of "Compendio de Ciencias Veterinarias" Journal 